\title{
ISOLASI DAN IDENTIFIKASI BAKTERI ASAM LAKTAT DARI LIUR BASA (LIMBAH SAYUR BAYAM DAN SAWI)
}

\author{
Sasmita, Aliansyah Halim, Aisyah Nur Sapriati, Sukriani Kursia \\ Sekolah Tinggi Ilmu Farmasi, Makassar, Sulawesi Selatan \\ Email: sasmitamita126@yahoo.com
}

\begin{abstract}
Lactic acid bacteria (BAL) is a gram-positive bacterium in the form of stems or round, not forming spores, anaerobic facultative fermentation and has the ability to ferment glucose into lactic acid. The purpose of this study was to isolate and identify lactic acid bacteria from spinach and mustard vegetable waste which can be used as food preservative. The isolation result was obtained by 10 isolates suspected as lactic acid bacteria. The isolates obtained were identified macroscopically, fermentation test, gram staining, spore staining and catalase test. From the macroscopic identification of samples of spinach and mustard, the isolates were white milk, rounded circular edges, kensitri surface and convex elevation. The fermentation test indicates that are heterofermentative and. All isolates obtained in the form of gram-positive bacteria had no negative spores and catalases and its alleged are Lactobasillus.
\end{abstract}

Key words : Lactic acid bacteria; isolation; identification

\section{PENDAHULUAN}

Fermentasi

dapat

dideskripsikan sebagai suatu proses perubahan secara biokimia pada bahan pangan oleh aktivitas mikroorganisme dan metabolit aktivitas enzim, yang dihasilkan oleh mikroorganisme tersebut. Mikrobia yang umumnya terlibat dalam fermentasi adalah bakteri, khamir dan kapang. ${ }^{3}$

Bakteri asam laktat merupakan kelompok mikroba yang berperan dalam proses fermentasi pangan.
Menurut Rahayu ${ }^{11}$ bakteri asam laktat dapat ditemukan pada berbagai jenis fermentasi buah-buahan (mangga, nangka, kedondong, durian dan sirsak), fermentasi sayuran (asinan sawi, rebung, terong, timun, bawang) dan fermentasi makanan (beras ketan dan tempe) serta fermentasi susu. Selain meningkatkan kualitas biji kakao, bakteri asam laktat juga mempunyai manfaat untuk kesehatan dengan menghasilkan aktivitas antimikroba terhadap bakteri patogen. 
Beberapa metabolit aktif yang dihasilkan oleh bakteri asam laktat yaitu asam laktat, etanol, hidroperoksida dan bakteriosin. Metabolit yang dihasilkan oleh bakteri tersebut merupakan agen yang dapat digunakan dalam membunuh bakteri. Salah satu yang digunakan sebagai antimikroba yaitu bakteriosin yang merupakan suatu senyawa peptida. Dilaporkan bahwa bakteriosin memegang peranan paling penting dalam menanggulangi infeksi akibat mikroorganisme. Selain itu asam laktat yang di produksi oleh BAL dapat menurunkan $\mathrm{pH}$ lingkungan. $\mathrm{pH}$ yang rendah dapat menghambat kontaminasi mikroba pembusuk dan juga membunuh mikroba patogen terutama yang ada didalam tubuh. ${ }^{6}$

Penelitian tentang isolasi BAL telah banyakdilakukan terutama pada produk-produk dagingmentah ataupun kalengan, produk susu (yoghurt, keju, dadih), fermentasi (tape, tempe, beer). Namun belum begitu banyak yang diisolasi daribuah-buahan dan sayursayuran tropis. Beberapa sumber memaparkan bahwa pada buahbuahan dan sayuran seperti durian, nanas, sirsak, cacao, pisang, mangga, tomat, kubis, asinan sawi, selada, kacang panjang dan lain sebagainya adalah potensia Isebagai sumber BAL. ${ }^{13}$

Penggunaan BAL sebagai bahan pengawet alami dapat dilakukan melalui dua cara yaitu penambahan kultur BAL sebagai starter pada produkpangan atau hanya menggunakan metabolit antimikroba yang diproduksioleh BAL sebagai pengawet alami. Penambahan kultur BAL sebagai startertelah banyak dikenal masyarakat dalam pembuatan produk fermentasi seperti yogurt, dadih, salami (sosis fermentasi), serta produk fermentasi lainnya, sedangkan pemanfaatan metabolit BAL (nisin, bakterioisin, hidrogen peroksida, asam lemah, reuterin dan diasetil) yang bersifat antimikroba telah lama digunakan dalam industri pengolahan pangan yang kemudian dikembangkan secara komersil. ${ }^{10}$

Limbah sayur yang berasal dari pasar merupakan kumpulan dari berbagai macam sayur yang telah dipilah karena mengalami kerusakan atau tidak layak dijual. Limbah sayur ini memiliki potensi sebagai pengawet maupun starter fermentasi karena kandungan asam yang tinggi, asam pada limbah sayur ini diduga berupa

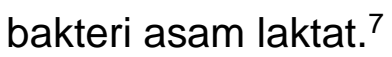

Selain itu masyarakat juga menghadapi masalah lain berupa 
permasalahan limbah. Salah satu limbah pertanian yang belum dimanfaatkan secara maksimal adalah limbah sayur. Hal ini ditunjukkan dengan jumlah limbah di Indonesia pada tahun 2008 mencapai 38,5 juta ton/tahun dengan presentase terbesar adalah limbah organik 58\% yang sebagian besar merupakan limbah sayur. ${ }^{8}$ Sedangkan data jumlah limbah sayur dari salah satu pasar tradisional Makassar menunjukkan bahwa dari total sampah oraganik ada sekitar $60 \%$ merupakan limbah sayur-sayuran dan 40\% merupakan limbah dedaunan. Limbah sayuran mudah busuk sehingga membuat lingkungan sekitar menjadi bau dan limbah sayur akan bernilai jika dimanfaatkan sebagai produk yang berguna.

\section{Beberapa}

penelitian menyatakan bahwa limbah sayur memiliki kandungan bakteri asam laktat yang memiliki kemampuan untuk memproduksi pengawet biologi dan dikenal mampu memperpanjang masa simpan makanan. Senyawa metabolit sekunder yang dimiliki oleh bakteri asam laktat berupa bakteriosin yang merupakan peptide dan memiliki potensi sebagai pengawet alami (biopreservatif) untuk menggantikan penggunaan pengawet kimia pada bahan makanan.Bakteriosin stabil, tahan terhadap proses pengolahan yang melibatkan asam danbasa, serta suhu panas dan dingin, dapat beradaptasi dengan baik pada lingkungan tempat diproduksinya, mempunyai stabilitas penyimpanan yang lebih baik, tidaktoksik dan mudah terdegradasi oleh enzim proteolitik, tidak mengubah cita rasa,tidak membahayakan mikroflora usus karena mudah dicerna enzim saluran pencernaan, dan mempunyai spektrum yang kecil terhadap aktivitas mikroorganisme.

\section{METODE PENELITIAN}

\section{Alat dan Bahan}

Adapun alat yang digunakan yaitu autoklaf, aluminium foil, batang pengaduk, bunsen, botol coklat, erlenmeyer, gelas beaker, inkubator, microwave, mikroskop, objek glass, ose, oven, pipet tetes, pingset, rak tabung, spoit, tabung reaksi, tabung durham, timbangan analitik, vial, dan wadah fermentasi. Adapun bahan yang digunakan yaitu aquadest, alkohol $70 \%$, cotton both, glukosa teknis, Gram A, Gram B, Gram C, dan Gram D, Hidrogen peroksida (H2O2), kalsium karbonat, kapas, kasa, medium MRSA (de Man Rogosa Sharpe Agar), MRSB (de Man Rogosa Sharpe Broth), malachite green, 
natrium klorida teknis, $\mathrm{pH}$ universal, plastik buah tissu.

\section{Prosedur Kerja}

\section{Pengambilan sampel}

Sampel penelitian yang digunakan adalah limbah sayur bayam dan sawi yang berasal dari pasar tradisional Daya, Makassar, Selawesi Selatan.

\section{Fermentasi Bakteri Asam Laktat ${ }^{14}$}

Limbah sayur yang telah diambil, dicuci, di rajang atau dikecilkan ukurannya, kemudian ditimbang. Fermentasi sampel dilakukan dengan merendam sampel dalam wadah fermentasi kaca kedap udara yang ditambahkan natrium klorida teknis $2 \% \quad(\mathrm{~b} / \mathrm{b}$ sampel), glukosa $0,5 \% \quad(\mathrm{~b} / \mathrm{b}$ sampel) dan aquadest masak hingga sampel terendam lalu ditindih dengan kantong plastik yang berisi air masak dengan konsentrasi Natrium klorida teknis 2\% dan glukosa $0,5 \%$.

\section{Isolasi Bakteri Asam Laktat ${ }^{15}$}

Sebanyak $1 \mathrm{~mL}$ dimasukkan ke dalam tabung reaksi, dibuat pengenceran 10-1 sampai 10-5, kemudian tiap pengeceran diambil 1 $\mathrm{mL}$ dimasukkan ke dalam cawan petri lalu ditambahkan medium MRSA (de Man Rogosa Sharpe Agar) $10 \mathrm{~mL}$, diinkubasi pada suhu $37^{\circ} \mathrm{C}$ selama 24 48 jam.

\section{Pemurnian Isolat}

Isolat dimurnikan dengan menggunakan medium MRSA (de Man Rogosa Sharpe Agar) dengan metode streak plate digores secara kuadran dan diinkubasi pada suhu $37^{\circ} \mathrm{C}$ selama 24-48 jam.

\section{Identifikasi Bakteri Asam Laktat} Identifikasi Makroskopik

Identifikasi bakteri asam laktat diidentifikasi menggunakan medium MRSA (de Man Rogosa Sharpe Agar) dan inkubasi pada suhu $37^{\circ} \mathrm{C}$.Pengamatan morfologi koloni dilakukan setelah mendapatkan biakan murni. Pengamatan makroskopis meliputi bentuk, warna, tepian, danelevasi koloni bakteri. Permukaan koloni dapat dilihat dari samping, dan tepi koloni dapat dilihat dari atas cawan. ${ }^{2}$

\section{Uji Tipe Fermentasi}

Isolat dimasukkan ke dalam tabung reaksi yang berisi medium MRSB (de Man Rogosa Sharpe Broth) dan tabung durham kemudian diinkubasi selama 24 jam, diamati kekeruhan dan gelembung.

\section{Uji Pewarnaan Gram}

\begin{tabular}{lrr}
\multicolumn{2}{c}{ Pewarnaan gram } & dilakukan \\
dengan mengambil & isolat \\
menggunakan cotton both lalu \\
digoreskan pada objek glass yang
\end{tabular}


telah disterilkan. Isolat bakteri kemudian dsigoreskan pada preparat kemudian ditetesi Gram A dan dibiarkan selama 1 menit, seanjutkan dicuci dengan aquadest dan dikeringkan. Isolat kemudian ditetesi dengan Gram B dibiarkan selama 1 menit, selanjutnya dicuci dengan aquadest dan dikeringkan. Selanjutnya ditetesi Gram C selama 30 detik kemudian dikeringkan. Isolat kemudian ditetesi gram D selama 30 detik lalu dicuci dan dikeringkan. Preparat diamati pada mikroskop, bakteri gram positif ditandai dengan warna ungu yang menandankan mampu menyerap warna Gram A dan bakteri gram negatif berwarna merah karna hanya menyerap warna Gram D.

\section{Uji Pewarnaan Spora} glass dan ditetesi pewarna malachite green dan dipanaskan diatas menangas air selama 5 menit dan dijaga agar tidak kering, lalu diamati secara mikroskopik, spora akan terlihat berwarna hijau sedangkan sel vegetatif berwarna merah.

\section{Uji Katalase}

Uji katalase dilakukan dengan meneteskan dua tetes $\mathrm{H}_{2} \mathrm{O}_{2} 3 \%$ pada isolat bakteri yang berumur 24 jam di atas kaca objek. Reaksi positif katalase ditandai dengan terbentuknya gelembung udara. Terbentuk gelembung udara menunjukkan bahwa bakteri menghasilkan enzim katalase yang dapat mengubah $\mathrm{H} 2 \mathrm{O} 2$ menjadi $\mathrm{H}_{2} \mathrm{O}$ dan $\mathrm{O}_{2}{ }^{2}$

Uji pewarnaan spora dilakukan dengan mengambil isolat bakteri

\section{HASIL PENELITIAN}

\section{Fermentasi Bakteri Asam Laktat.}

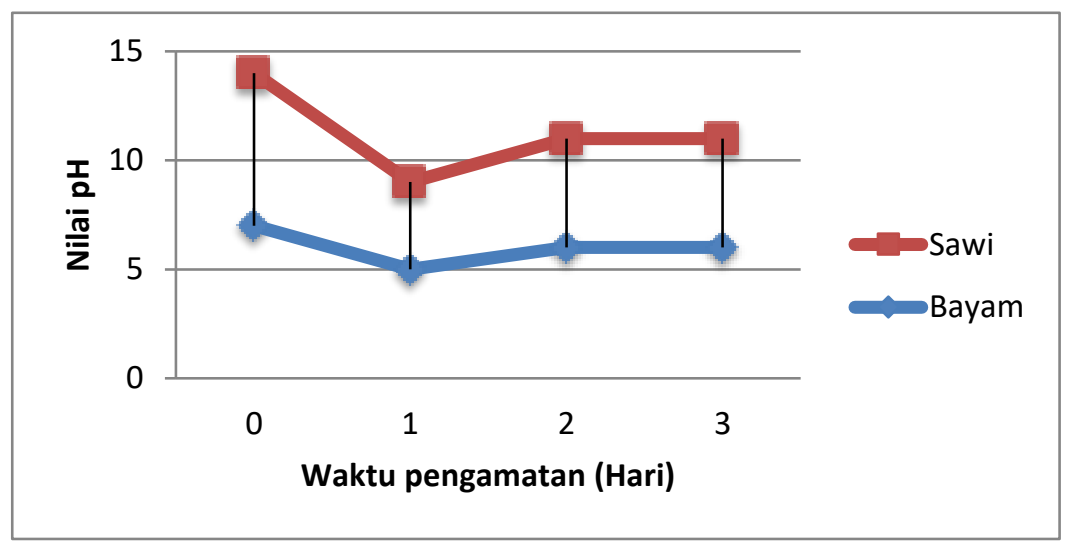

Gambar 1. Hasil pengukuran $\mathrm{pH}$ fermentasi bayam dan sawi 


\section{Hasil Isolat dan Identifikasi Makroskopik}

Tabel 1. Hasil Pengamatan Mikroskopik isolat bakteri asam laktat

\begin{tabular}{|c|c|c|c|c|c|c|}
\hline Sampel & Isolat & Bentuk & Tepian & Warna & Permukaan & Diameter \\
\hline \multirow{6}{*}{ Bayam } & 1 & \multirow{6}{*}{ Bulat } & \multirow{6}{*}{ Lingkaran } & \multirow{6}{*}{ Putih susu } & \multirow{6}{*}{ Kosentris } & $2,3 \mathrm{~mm}$ \\
\hline & 2 & & & & & $1,5 \mathrm{~mm}$ \\
\hline & 3 & & & & & $1,23 \mathrm{~mm}$ \\
\hline & 4 & & & & & $1,28 \mathrm{~mm}$ \\
\hline & 5 & & & & & $3,03 \mathrm{~mm}$ \\
\hline & 6 & & & & & $1,35 \mathrm{~mm}$ \\
\hline \multirow{4}{*}{ Sawi } & 1 & \multirow{4}{*}{ Bulat } & \multirow{4}{*}{ Lingkaran } & \multirow{4}{*}{ Putih susu } & \multirow{4}{*}{ Kosentris } & $1,03 \mathrm{~mm}$ \\
\hline & 2 & & & & & $2,05 \mathrm{~mm}$ \\
\hline & 3 & & & & & $1,5 \mathrm{~mm}$ \\
\hline & 4 & & & & & $2,5 \mathrm{~mm}$ \\
\hline
\end{tabular}

\section{Identifikasi Mikroskopik dan Identifikasi Uji Katalase}

Pada pengecatan Gram telihat bahwa sel bakteri berbentuk basil dan berwarna biru, sedangkan pada pewarnaan spora tidak terdapat spora yang melekat pada sel bakteri.
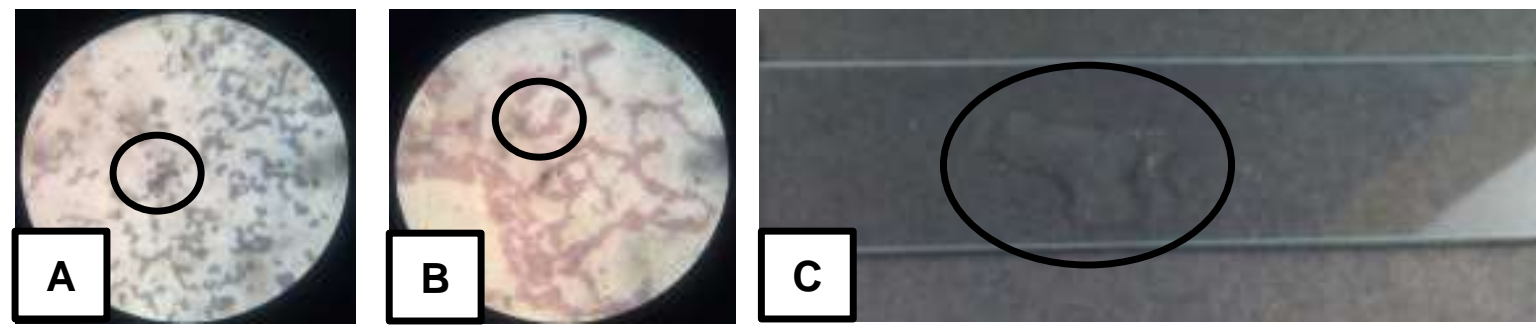

Gambar 2. (A) Sel berbentuk basil dan berwarna biru; (B) Terlihat tidak ada spora melekat pada dinding sel; (C) Hasil uji katalase, tidak ada gelembung yang terbentuk setelah ditetesi $\mathrm{H}_{2} \mathrm{O}_{2}$.

\section{PEMBAHASAN}

\section{Fermentasi Bakteri Asam Laktat}

Pengambilan sampel limbah bayam dan sawi di Pasar Daya Baru Makassar dilakukan pada sore hari karena pada waktu tersebut merupakan waktu pembersihan dan pengumpulan limbah pasar setelah aktivitas perdagangan selama seharian. Pemilihan limbah sayur dikarenakan potensinya yang cukup besar yaitu jumlahnya cukup banyak, mudah diperoleh dan digunakan sebagai antibakteri karena kandungan bakteri asam laktat. ${ }^{13}$

Sampel diperoleh dari pasar tradisional Daya, Makassar, Sulawesi Selatan. Sampelyang telah diambil kemudian dicuci dan disortasi basah.Tujuan sortasi basah adalah untuk memisahkan kotoran-kotoran atau bahan-bahan asing lainnya ${ }^{17}$; 
Isolasi dan identifikasi bakteri asam laktat dari liur basa (limbah sayur bayam dan sawi)

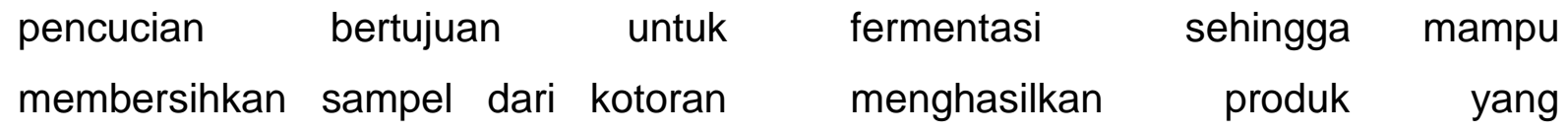
yang melekat, seperti tanah dan mempunyai nilai ekonomi yang tinggi21 cendawan ${ }^{16}$; perajangan bertujuan setelah itu dilakukan pengukuran untuk memperkecil ukuran bahan serta $\quad \mathrm{pH}$. Menurut Sari ${ }^{24}$, proses fermentasi untuk mempercepat proses pengeringansampel limbah.

Sebanyak masing-masing $200 \mathrm{~g}$ sampel limbah digunakan pada tahap fermentasi. Fermentasi merupakan proses pemecahan senyawa kompleks menjadi senyawa yang lebih sederhana dengan bantuan enzim mikroorganismesehingga mampu menghasilkan suatu produk melalui penggunaan jasa biakan mikroba fermentasi, baik biakan murni maupun campuran dan perubahan substrat menjadi bahan yang mempunyai nilai tambah (adding value) atau komponen bahan mempunyai fungsi spesifik ${ }^{21}$. Proses fermentasi dilakukan dengan cara dimasukkan ke dalam toples yang kedap udara kemudian ditambahkan natrium klorida teknis $2 \%$ (b/b sampel), glukosa 0,5\% (b/b sampel). Tujuan penambahan garam berperan sebagai penghambat selektif pada mikroorganisme pencemar tertentu ${ }^{20}$, kondisi kedap udara disebabkan karena bakteri asam laktat bersifat fakultatif anaerob ${ }^{19}$ sedangkan glukosa sebagai sumber energi atau sumber karbon pada proses menghasilkan kondisi asam dan perubahan $\mathrm{pH}$. Hasil pengukuran $\mathrm{pH}$ fermentasi sayur bayam dan sawi menunjukkan bahwa terjadi perubahan nilai $\mathrm{pH}$ dapat dilihat pada gambar 1 . Penurunan nilai tersebut mengindikasikan adanya aktivitas mikroba dalam menguraikan karbohidrat..

Dari gambar 1. Perubahan $\mathrm{pH}$ menjadi lebih asam karena proses fermentasi menghasilkan asam laktat yang mengubah asam organik seperti asam laktat, asam asetat, asam formiat, diasetil, dan hidogen peroksida pada sayuran ${ }^{5}$, perubahan ini disebabkan oleh pecahnya senyawa kompleks $\mathrm{NaCl}$ menjadi ion $\mathrm{Na}^{+}$dan $\mathrm{Cl}^{-}$. Ion $\mathrm{NaCl}$ dibutuhkan asam laktat sebagai substitusi ion-ion $\mathrm{K}^{+}$ketika terjadi difusi, sedangkan ionion $\mathrm{Cl}^{-}$berikatan menyebakan ketersediaan air dalam bahan berkurang dan menyebabkan suasana lingkungan menjadi asam karena terbentuknya $\mathrm{HCl}^{18}$. Hal ini sejalan dengan pernyataan Azizah, 2012 semakin lama fermentasi dan semakin banyak glukosa yang ditambahkan, 
Isolasi dan identifikasi bakteri asam laktat dari liur basa (limbah sayur bayam dan sawi)

mikroorganisme berkembang biak semakin banyak, karena glukosa merupakan substrat nutrien yang dibutuhkan oleh mikroba untuk tumbuh maupun menghasilkan produk fermentasi.Selain itu BAL dapat mengkonversi gula menjadi asam organik (laktat dan asetat) yang akan disekresikan keluar sel sehingga menyebabkan penurunan $\mathrm{pH}$ dan mendegradasi karbohidrat untuk digunakan sebagai sumber nutrien bagi mikroorganisme pengganggu atau pembusuk ${ }^{11}$. Bakteri asam laktat dapat tumbuh di kisaran $\mathrm{pH}$ asam sehingga $\mathrm{pH}$ hari kedua $(\mathrm{pH}+1)$ diisolasi untuk diidentifikasi

\section{Isolasi Bakteri Asam Laktat}

Isolasi bakteri merupakan sebuah cara pemurnian isolat menggunakan media selektif de Men Rogrosa Sharpe Agar (MRSA) dengan kondisi yang sama berulang kali sehingga diperoleh isolat tunggal ${ }^{15}$. Sampel yang diambil merupakan hasil fermentasi hari pertama karena penurunan $\mathrm{pH}$ pada kedua sampel berada padapH 5 dan sawi pada $\mathrm{pH} 4$. Isolasi dilakukan menggunakan teknik pengenceran hingga 10 menggunakan media selektif MRSA dan di inkubasi pada suhu $37^{\circ} \mathrm{C}$ selama $1 \times 24$ jam. Hasil isolasi sampel bayam didapatkan sebanyak 6 isolat pada pengenceran $10^{-1}$ dan pada sampel sawi sebanyak 4 isolat pada pengenceran 10-5. Masingmasing isolat hasil fermentasi kemudian dimurnikan dengan metode goresan kuadran pada media selektif MRSA padat dan diinkubasi pada suhu $37^{\circ} \mathrm{C}$ selama $1 \times 24$ jam.

\section{Identifikasi Bakteri Asam Laktat (BAL) \\ Isolat yang diperoleh dari} sampel bayam dan sawi kemudian diidentifikasi secara makroskopik, mikroskopik meliputi bentuk sel, pewarnaan Gram dan pewarnaan Spora serta uji biokimia. Karakterisasi dapat dilakukan berdasarkan sifatmorfologi koloni, morfologi sel dan biokimia9 .

Identifikasi secara makroskopik dilakukan dengan memilih strain isolat yang berbeda pada masing-masing sampel bayam dan sawi setelah proses isolasi pertama dan melihat langsung isolat yang tumbuh pada mediaagar meliputi warna, bentuk, tepi, permukaan serta sudut elevasi yang terbentuk pada isolat ${ }^{4}$.

Dari hasil identifikasi makroskopik sampel bayam dan sawi didapatkan isolat yang berwarna putih susu, berbentuk bulat tepian lingkaran, permukaan konsentris dan elevasi cembung serta diameter rata-rata 
berkisar antara 1,28-3,0 seperti yang terlihat pada tabel 1.

\section{Identifikasi Uji Tipe Fermentasi}

Pengujian tipe fermentasi menggunakan media spesifik deMen Rogrosa Sharpe Broth (MRSB). Berdasarkan uji tipe fermentasi diperoleh bahwa isolat tergolong tipe heterofermentatif yang ditandai adanya pembentukan gelembung gas yang tertampung dalam tabung durham. Menurut Jay ${ }^{23}$ dalam Santi Susilawati ${ }^{12}$ BAL yang menghasilkan asam laktat, karbondioksida $\left(\mathrm{CO}_{2}\right)$, dan etanol termasuk dalam kelompok heterofermentatif sedangkan BAL yang menghasilkan asam laktat sebagai hasil utama dari fermentasi glukosa disebut homofermentatif.

Identifikasi mikroskopik bertujuan untuk mengamati bentuk dan jenis bakteri asam laktat yang di isolasi. Teknik pewarnaan yang dilakukan yaitu dengan pewarnaan Gram dan pewarnaan spora dan diamati pada mikroskop perbesaran 100x. Pengecatan Gram atau metode Gram merupakan suatu metode empiris untuk membedakan spesies bakteri menjadi dua kelompok besar yaitu gram positif dan gram negatif berdasarkan sifat kimia dan fisika dinding sel bakteri. ${ }^{1}$
Hasil identifikasi mikroskopik isolat BAL fermentasi bayam dan sawi menunjukkan bahwa isolat termasuk jenis Gram positif dan tidak memiliki spora, Ibrahim (4) menyatakan bahwa BAL termasuk bakteri gram positif karena mengikat warna kristal violoet (Gram A) sehingga tampak berwarna ungu. BAL merupakan bakteri yang tidak membentuk spora sehingga yang tampak adalah sel vegetatif yang menghasilkan warna merah muda pada akhir tahap pewarnaan. ${ }^{22}$

\section{Identifikasi Uji Katalase}

Pengujian katalase adalah pengujian secara biokimiawi yang memperlihatkan aktivitas dari bakteri yang menghasilkan enzim katalase ditandai dengan terbentuknya gelembung pada pengujian yang menandakan reaksi positif. ${ }^{4}$

Hasil uji katalase isolat bayam dan sawi pada gambar 1 menunjukkan termasuk kategori katalase negatif dikarenakan tidak adanya gelembung pada object glass. Bakteri asam laktat tidak memproduksi enzim katalase yang dapat mengubah hidrogen peroksida menjadi air dan oksigen serta berkaitan dengan kemampuan bakteri asam laktat yang hanya membutuhkan sedikit oksigen untuk dapat hidup. ${ }^{4}$ 
Dari hasil isolasi dan identifikasi diduga bahwa hasil isolat bakteri asam laktat adalah genus Lactobacillus. Hal ini sejalan karakteristik yang dikemukakan oleh Holt et al 1994 dalam Borgeys Manual of Determinative Bacteriology mengatakan bahwa bakteri genus Lactobacillus termasuk gram positif, tidak berspora, fakultatif anaerob. Hal ini juga diperkuat oleh pernyataan Ray 25 menyatakan bahwa Lactobaciillus banyak dijumpai pada sayuran yang memiliki ciri sel berbentuk batang dengan ukuran bentuk yang seragam.

\section{KESIMPULAN}

Isolat bakteri asam laktat sampel bayam dan sawi memiliki karakteristik berwarna putih susu, berbentuk bulat tepian lingkaran, permukaan konsentris dan elevasi cembung. Hasil identifikasi menunjukkan bahwa termasuk golongan bakteri Gram positif berbentuk basil, tidak mengandung spora, bersifat katalase negatif dan tipe fermentasi heterofermentatif. Isolat Bakteri asam laktat tersebut diduga genus Lactobasillus

\section{DAFTAR PUSTAKA}

1. Aditya, Mashoffa. Teknik Pewarnaan Bakteri. Jakarta : UI Press, 2010.
2. Hadioetomo RS. Mikrobiologi Dasar Dalam Praktek Teknik dan ProsedurDasar Laboratorium. Jakarta : Gramedia, 1993.

3. Hidayat Nur, Masdiana CP, Sri $\mathrm{H}$. Mikrobiologi Industri. Yogyakarta : Penerbit Andi, 2006.

4. Ibrahim, Arsyik et al. Isolasi dan Identifikasi Bakteri Asam Laktat (BAL) dari Buah Mangga (Mangifera indika. L). Jurnal IImiah Manuntung. 2015;1(2):159-163

5. Jenie BSL, Nuratifa, Suliantari. Peningkatan Keamanan dan Mutu Simpan Pindang Ikan Kembung (Rastrelliger sp.) dengan Aplikasi Kombinasi Natrium Asetat, Bakteri Asam Laktat dan Pengemasan Vakum. Jurnal Teknologi dan Industri Pangan. 2001;12(1): 21-27.

6. Lawalata, Helen J, Sembiring L, Rahayu ES. Bakteri Asam Laktat Pada Bakasang dan Aktivitas Penghambatannya Terhadap Bakteri Patogen dan Pembusuk. Prosiding Seminar Nasional Biologi. Yogyakarta : Fakultas Biologi UGM, 2010.

7. Mulyanto A. Potensi Limbah Sayur Menjadi Starter Fermentasi. Semarang : Jurnal Kesehatan. 2009;2.

8. Nurmiati. Analisis Pemanfaatan Kelistrikan dari Limbah Sayur dan Buahsebagai Energi Listrik Alternatif di Pasar Sungguminasa (Skripsi). Makassar : UIN Alauddin Makassar, 2016.

9. Purwoko T. Fisiologi Mikroba. Jakarta : Bumi Aksara, 2007.

10. Pasetya R. Perubahan Kimia dan Mikrobiologi dalam Fermentasi 
Rebung (Skripsi). Bogor: Fakultas Teknologi Pertanian, Institut Pertanian Bogor, 1985.

11. Rahayu, E. S. dan Margino, S. 1997. Bakteri Asam Laktat: Isolasi danldentifikasi. Materi Workshop. Yogyakarta : Universitas Gadjah Mada.

12. Susilawati, Santi. Isolasi dan Karakterisasi Bakteri Asam Laktat (BAL) dari Fermentasi Air Cucian Beras (Skripsi). Jakarta :UIN Syarif Hidayatullah, 2016.

13. Yuni Nurisva Sari Maya, Syukur YN, Sari SJ. Isolasi, Karakterisasi, dan Identifikasi DNA Bakteri Asam Laktat (BAL) Yang Berpotensi Sebagai Antimikroba dari Fermentasi Markisa Kuning (Passiflora edulis Var. Flavicarpa). J Kimia Unand. 2013;2(2): 81-91.

14. Nesha PRMS. Studi Pengolahan dan Lama Penyimpanan Saus Cabai dari Bahan Dasar Cabai Merah (Capsicum annuum L.) dan Cabai Rawit (Capsicum frutencens L). yang di Fermentasi (Skripsi). Makassar : Universitas Hasanuddin, 2012.

15. Nur, Farmawati. Hafsan, Andi Wahdiniar. Isolasi Bakteri Asam Laktat Berpotensi Probiotik pada Dangke, Makanan Tradisional dari Susu Kerbau di Curio Kabupaten Enrekang. Jurnal Ilmiah Biologi Biogenesis 3. 2015.

16. Sobir dan Rodame N. Bertanam Durian Unggul. Bogor : Penerbit Swadaya, 2010.
17. Setiawan, Hendra. Kiat Sukses Budidaya Cabai Hidroponik. Yogyakarta : Huta Media, 2017.

18. Desniar, Rusmana, Suwanto IA, Mubarik NR. Senyawa Antimkroba yang dihasilkan Oleh Bakteri Asam Laktat Asal Bekasam. Jurnal Akuatika. 2012.

19. Widodo. Bakteri Asam Laktat Strain Lokal. Yogyakarta: Gadjah Mada University Press, 2018.

20. Utama CS, Mulyanto A. Potensi Limbah Pasar Sayur Menjadi Starter Fermentasi. Semarang : Universitas Diponegoro, 2009.

21. Bachruddin, Zaenal. Teknologi Fermentasi pada Industri Peternakan. Yogyakarta : Gadjah Mada Univeristy Press, 2014.

22. Laily, Ikrimah N, Rohula U, Esti W. Isolasi dan Karakterisasi Bakteri Asam Laktat Penghasil Riboflavin dari Produk Fermentasi Sawi Asin. J Aplikasi Teknologi Pangan.2013;2(4):128.

23. Jay JM. Modern Food Microbiology $4^{\text {th }}$ edition. New York : Chapman and Hall, 1992.

24. Sari, Rohma A, Risa N, Puji A. Karakterisasi Bakteri Asam Laktat Genus Leuconostoc dari Pekasam Ale-Ale Hasil Formulasi Skala Laboratorium. JKK. 2012.

25. Ray B. Fundamental Food Microbiology. Second edition. Boca Raton : CRC Press, 2001. 